\title{
Effects of Forchlorfenuron and Abscisic Acid on the Quality of 'Flame Seedless' Grapes
}

\author{
M. Cecilia Peppi ${ }^{1}$ and Matthew W. Fidelibus \\ Department of Viticulture and Enology, University of California, One Shields \\ Avenue, Davis, CA 95616 \\ Additional index words. anthocyanins, ABA, CPPU, table grapes, Vitis vinifera
}

\begin{abstract}
Forchlorfenuron (CPPU), a synthetic cytokinin, applied after fruit set increases the size and firmness of table grapes (Vitis vinifera $\mathrm{L}$.) beyond what is possible without CPPU treatment. However, treatment with CPPU may inhibit coloring of 'Flame Seedless' grapes, limiting its use in growing areas where color has been consistently poor. In contrast, application of abscisic acid (ABA) to 'Flame Seedless' grapes may cause fruit softening, which is undesirable, but its primary effect is to increase anthocyanin content and fruit color. Thus, we hypothesized that application of CPPU followed by ABA might increase the size and firmness of 'Flame Seedless' grapes without excessively inhibiting coloring. Grapes were treated with 0 or $20 \mathrm{~g} \cdot \mathrm{ha}^{-1}$ CPPU (applied at fruit set) and 0,300 , or $600 \mathrm{mg} \cdot \mathrm{L}^{-1} \mathrm{ABA}$ (applied at veraison) in 2005 and with $0,5,10,15$, or $20 \mathrm{~g} \cdot \mathrm{ha}^{-1}$ CPPU and $0,200,400$, or $600 \mathrm{mg} \cdot \mathrm{L}^{-1} \mathrm{ABA}$ in 2006. Both plant growth regulators (PGRs) increased berry mass, but grapes treated with CPPU were as firm, or firmer, than nontreated grapes, whereas those treated with ABA were of similar or lesser firmness. Treatment with CPPU generally reduced soluble solids and red berry color, whereas treatment with ABA reduced titratable acidity and increased red color. The PGRs did not interact to affect any of the fruit quality variables measured, so beneficial effects of CPPU or ABA were apparent whether the grapes were treated with either or both PGRs. Thus, the combined use of CPPU and ABA may be a desirable cultural practice for 'Flame Seedless'.
\end{abstract}

Most seedless table grapes are treated with gibberellic acid $\left(\mathrm{GA}_{3}\right)$ to increase berry size and uniformity (Diaz and Maldonado, 1992; Dokoozlian et al., 1994; Reynolds et al., 1992; Wolf et al., 1994). Application of the synthetic cytokinin forchlorfenuron [N-(2-chloro-4-pyridyl)- $\mathrm{N}^{\prime}$-phenylurea], commonly known as CPPU, can further increase berry size and may also improve fruit firmness (Dokoozlian et al., 1994; Melillo, 2005; Nickell, 1986, Oswald, 1994; Reynolds et al., 1992; Wolf et al., 1994; Zabadal and Bukovac, 2006). 'Flame Seedless', California's most planted red table grape, has a particularly strong response to CPPU in regard to berry size (Diaz and Maldonado, 1992; Melillo, 2005; Oswald, 1994; Wolf et al., 1994), but such applications can severely impair red color development of 'Flame Seedless' berries, so the use of CPPU is generally not recommended.

\footnotetext{
Received for publication 30 July 2007. Accepted for publication $13 \mathrm{Sept} .2007$.

This research was made possible by awards from the California Table Grape Commission and the California Competitive Grant Program for Research in Viticulture and Enology and from the Valent BioSciences Corporation.

We acknowledge the assistance of Kimberley Cathline and Jorge Aguilar Osorio and the helpful comments on the manuscript of Jennifer HashimBuckey and Rhonda Smith.

${ }^{1}$ To whom reprint requests should be addressed; e-mailmcpeppi@ucdavis.edu
}

Abscisic acid (ABA) is an antagonist of some plant growth regulators, including cytokinins (Taiz and Zeiger, 2002). Recently, we showed that application of ABA can increase the anthocyanin content and improve the color of 'Flame Seedless' grapes, but it also causes fruit softening, which is undesirable (Peppi et al., 2006). The combined use of CPPU and ABA might be desirable if large, firm berries of acceptable color are the result. Thus, the objective of this study was to evaluate if the application of CPPU followed by ABA might increase the size and firmness of 'Flame Seedless' grapes without excessively inhibiting coloring.

\section{Materials and Methods}

Plant material and growing conditions. The experiments were conducted on mature own-rooted 'Flame Seedless' vines at the Kearney Agricultural Center (KAC), Parlier, CA (2005) or in a commercial vineyard near Fowler, CA (2006). Vines at the KAC were trained to bilateral cordons, spur-pruned, and trellised to the traditional California Tsystem (Winkler et al., 1974) spaced $2.4 \mathrm{~m}$ within rows and $3.6 \mathrm{~m}$ between rows. Vines at the commercial vineyard were trained to quadrilateral cordons, cane-pruned, and supported by an open-gable trellis. Rows of both vineyards were oriented east to west. Standard cultural practices for 'Flame Seedless' table grapes were followed both years (Dokoozlian and Hirschfelt, 1995; Peppi et al., 2006) with the exception that ethephon was not applied. Experimental vines were selected on the basis of uniformity of vegetative growth and crop load after fruit set.

Chemicals. Forchlorfenuron, CPPU (Prestige), and ABA ( $S$-abscisic acid experimental formula) were both obtained from Valent BioSciences Corporation, Libertyville, IL.

Experimental design. In 2005, solutions of CPPU ( 0 or $\left.20 \mathrm{~g} \cdot \mathrm{ha}^{-1}\right)$ and ABA $(0,300$, or $\left.600 \mathrm{mg} \cdot \mathrm{L}^{-1}\right)$ were applied to clusters in a factorial treatment structure having a randomized complete block design (RCBD) with individual vines as blocks and clusters as experimental units. Solutions of CPPU were applied 1 week after fruit set (27 May) and those of ABA were applied at veraison $(\approx 10 \%$ of the berries beginning to soften, 21 June for non-CPPU-treated clusters). Abscisic acid was applied to CPPU-treated clusters 1 week later (27 June) than non-CPPUtreated clusters to take into account the delay in veraison caused by CPPU that year. The CPPU and ABA factors were nested within harvest date (14 July and 21 July). In 2006, five CPPU levels $\left(0,5,10,15\right.$, and $\left.20 \mathrm{~g} \cdot \mathrm{ha}^{-1}\right)$ and four ABA concentrations $(0,200,400$, and $600 \mathrm{mg} \cdot \mathrm{L}^{-1}$, assuming a spray volume of $1000 \mathrm{~L} \cdot \mathrm{ha}^{-1}$ ) were tested in a factorial experiment using a RCBD. The CPPU was applied 1 week after fruit set (31 May) and ABA was applied at veraison (21 June). Two adjacent vines formed each block and fruit were harvested once (17 July). Each year treatments were applied to the clusters with a handheld sprayer until runoff and there were eight replicates for each treatment and harvest.

Fruit analyses. At harvest, clusters were weighed, 20 berries were clipped from each cluster with their pedicels attached and kept for firmness and anthocyanin analyses, and 50 berries were removed and used for the remaining fruit quality measurements. The 50 berries were first weighed to obtain mean berry weight and then placed in a trough so that their ends or equators gently touched to measure mean berry length and diameter, respectively (Dokoozlian et al., 1994). Berries were then homogenized in a blender, the juice obtained was filtered, and soluble solids were measured with a temperature-compensating digital refractometer (Palette 101; Atago, Farmingdale, NY). Titratable acidity was determined by titration of a 5-mL aliquot of juice diluted in deionized water $(1: 4$, by volume) with $0.133 \mathrm{~N} \mathrm{NaOH}$ to an $8.2 \mathrm{pH}$ end point using an automatic titrator $(900 \mathrm{~A}$; Orion Research, Boston) and expressed as grams of tartaric acid per liter of juice. Ten of the 20 clipped berries were used for firmness analysis. On a small area at one side of the equator, skin was removed with a razor blade exposing the flesh. Mesocarp puncture resistance measurements, indicators of fruit firmness, were made on the exposed flesh using a 4.8-mm-diameter cylindrical probe affixed to a U.C. fruit firmness tester (Jensen et al., 1975; Peppi et al., 2006). The remaining 10 berries were used for color and anthocyanin 
measurements. Color characteristics [lightness $\left(\mathrm{L}^{*}\right)$, chroma $\left(\mathrm{C}^{*}\right)$, and hue $\left.\left(\mathrm{h}^{\circ}\right)\right]$ were measured on three equidistant points around the equator of each berry using a Minolta colorimeter (CR-200, Minolta, Ramsey, NJ) (Peppi et al., 2006). The lightness of color increases with $\mathrm{L}^{*}$, the purity of color increases with $\mathrm{C}^{*}$, and $\mathrm{h}^{\circ}$ refers to points of the color wheel with red at $0^{\circ}$ and yellow at $90^{\circ}$ (McGuire, 1992). After measuring their color, the berries were frozen at $-20{ }^{\circ} \mathrm{C}$ until anthocyanins were extracted as described by Peppi et al. (2006). Briefly, two 10-mm diameter skin disks were removed from the equator of each frozen berry, rinsed, blotted dry with paper towels, and placed in polystyrene tubes with methanol at room temperature and in the dark for $48 \mathrm{~h}$. Tubes were then manually agitated, a 2-mL aliquot was acidified with $1 \% \mathrm{HCl}$, and absorbance of each sample was determined at $520 \mathrm{~nm}$ using a spectrophotometer (Milton Roy 601; Spectronic, Rochester, NY). Readings were expressed as milligrams of total anthocyanins as malvidin-3-glucoside per area of skin $\left(\mathrm{cm}^{2}\right)$ (Peppi, 2004).

\section{Results}

2005 experiments. Application of CPPU or ABA increased berry weight, length, and diameter (Table 1), but the two plant growth regulators and the harvest date did not interact to affect those variables (data not shown). Soluble solids, but not titratable acidity, were reduced by CPPU (Table 1). On the contrary, ABA did not affect soluble solids, but the 300 and $600-\mathrm{mg} \cdot \mathrm{L}^{-1} \mathrm{ABA}$ treatments decreased juice titratable acidity. There was no interaction among CPPU, ABA, and harvest date in their effect on soluble solids or titratable acidity (data not shown). Berry firmness declined between the first and second harvest (Table 2), but harvest date did not affect any other variable measured and, except for $\mathrm{C}^{*}$, harvest date did not interact with the other factors tested (Tables 1 and 2).

Puncture resistance of the berries, an indicator of fruit firmness, was increased by CPPU but not by ABA (Table 2). On the other hand, anthocyanin content was decreased by CPPU and increased by 300 and $600 \mathrm{mg} \cdot \mathrm{L}^{-1}$ ABA (Table 2). Treatment with CPPU increased lightness and $\mathrm{h}^{\circ}$ (Table 2), and CPPU interacted with harvest date to affect $\mathrm{C}^{*}$; at the first harvest, application of CPPU increased $\mathrm{C}^{*}$ from 10.09 to 17.32 and at the second harvest CPPU increased $\mathrm{C}^{*}$ from 8.28 to 17.86. Application of $\mathrm{ABA}$ reduced the values of the three color characteristics in a dose-dependant manner (Table 2).

2006 experiments. Application of 15 $\mathrm{g} \cdot \mathrm{ha}^{-1}$ CPPU increased berry weight and diameter, but not berry length, whereas application of ABA increased berry weight, length, and diameter (Table 3). Soluble solids were reduced by CPPU but not by ABA, and titratable acidity was unaffected by CPPU but reduced by ABA (Table 4). Puncture resistance was unaffected by CPPU but was decreased by increasing concentrations of ABA (Table 4). Anthocyanins were increased by ABA and decreased by CPPU (Table 4). Application of CPPU increased $\mathrm{L}^{*}, \mathrm{C}^{*}$, and $\mathrm{h}^{\circ}$, whereas application of ABA did the opposite (Figs. 1, 2, and 3). Applications of CPPU and ABA did not interact to affect berry color characteristics, and berries treated with CPPU and $400 \mathrm{mg} \cdot \mathrm{L}^{-1} \mathrm{ABA}$ or greater had $h^{\circ}$ that were similar to or lower than those of fruit with no CPPU or ABA (Figs. 1 and 3).

\section{Discussion}

Treatment with CPPU generally increased all the variables related to berry size, but the results were more striking in 2005 than in 2006. This could be because berry weight, length, and diameter were considerably less in 2005 than 2006, suggesting that there was

Table 1. Effect of harvest date, CPPU, and ABA on berry weight, length and diameter, and soluble solids and titratable acidity (TA) of Flame Seedless, 2005.

\begin{tabular}{llcccc}
\hline Factor & $\begin{array}{c}\text { Berry } \\
\mathrm{wt}(\mathrm{g})\end{array}$ & $\begin{array}{c}\text { Berry length } \\
(\mathrm{mm})\end{array}$ & $\begin{array}{c}\text { Berry diam. } \\
(\mathrm{mm})\end{array}$ & $\begin{array}{c}\text { Soluble solids } \\
\left({ }^{\circ} \mathrm{Brix}\right)\end{array}$ & $\begin{array}{c}\mathrm{TA} \\
\left(\mathrm{g} \cdot \mathrm{L}^{-1}\right)\end{array}$ \\
\hline $\begin{array}{l}\text { Harvest }(\mathrm{H}) \\
\quad \text { 14 July }\end{array}$ & $4.0^{\mathrm{z}}$ & 18.6 & 18.6 & 16.4 & 7.28 \\
$\quad$ 21 July & 4.2 & 19.1 & 18.9 & 16.6 & 6.88 \\
CPPU $\left(\mathrm{g} \cdot \mathrm{ha}^{-1}\right)$ & & & & & \\
$\quad 0$ & $3.2 \mathrm{~b}^{\mathrm{y}}$ & $18.0 \mathrm{~b}$ & $17.0 \mathrm{~b}$ & $19.3 \mathrm{a}$ & 6.95 \\
$\quad 20$ & $4.5 \mathrm{a}$ & $19.2 \mathrm{a}$ & $19.5 \mathrm{a}$ & $15.3 \mathrm{~b}$ & 7.15 \\
ABA $\left(\mathrm{mg} \cdot \mathrm{L}^{-1}\right)$ & & & & & \\
$\quad 0$ & $3.4 \mathrm{c}^{\mathrm{x}}$ & $17.7 \mathrm{c}$ & $17.7 \mathrm{c}$ & 15.8 & $8.43 \mathrm{a}$ \\
300 & $4.2 \mathrm{~b}$ & $18.8 \mathrm{~b}$ & $18.8 \mathrm{~b}$ & 16.8 & $6.70 \mathrm{~b}$ \\
600 & $4.8 \mathrm{a}$ & $19.9 \mathrm{a}$ & $19.7 \mathrm{a}$ & 17.0 & $6.24 \mathrm{~b}$ \\
Significance & & & & & \\
$\quad$ H & 0.9849 & 0.8828 & 0.8964 & 0.2774 & 0.1645 \\
CPPU & $<0.0001$ & 0.0133 & $<0.00001$ & $<0.0001$ & 0.2524 \\
ABA & $<0.0001$ & $<0.0001$ & $<0.0001$ & 0.2476 & 0.0030 \\
\hline
\end{tabular}

${ }^{\mathrm{z}}$ Values are $\mathrm{H}$ means, $\mathrm{n}=48$.

${ }^{\mathrm{y}} \mathrm{CPPU}$ means, $\mathrm{n}=48$.

${ }^{\mathrm{x}} \mathrm{ABA}$ means, $\mathrm{n}=32$.

Means followed by a different letter within columns and factors, are significantly different according to Duncan's multiple range test $(P \leq 0.05)$.

$\mathrm{CPPU}=$ forchlorfenuron; $\mathrm{ABA}=$ abscisic acid.

Table 2. Effect of harvest date, CPPU, and ABA on firmness, anthocyanins, lightness $\left(\mathrm{L}^{*}\right)$, chroma $\left(\mathrm{C}^{*}\right)$, and hue $\left(\mathrm{h}^{\circ}\right)$ of Flame Seedless grape skins, 2005.

\begin{tabular}{lccrrr}
\hline Factor & Firmness $(\mathrm{g})$ & Anthocyanins $\left(\mathrm{mg} \cdot \mathrm{cm}^{-2}\right)$ & $\mathrm{L}^{*}$ & $\mathrm{C}^{*}$ & $\mathrm{~h}^{\circ}$ \\
\hline Harvest date & & & & & \\
$\quad$ 14 July & $711 \mathrm{a}^{\mathrm{z}}$ & 0.013 & 40.79 & 14.84 & 59.5 \\
21 July & $633 \mathrm{~b}$ & 0.011 & 41.78 & 15.25 & 61.8 \\
CPPU $\left(\mathrm{g} \cdot \mathrm{ha}^{-1}\right)$ & & & & & \\
$\quad 0$ & $496 \mathrm{~b}^{\mathrm{y}}$ & $0.022 \mathrm{a}$ & $35.75 \mathrm{~b}$ & 9.32 & $20.4 \mathrm{~b}$ \\
$\quad 20$ & $753 \mathrm{a}$ & $0.008 \mathrm{~b}$ & $43.74 \mathrm{a}$ & 17.59 & $78.6 \mathrm{a}$ \\
ABA $\left(\mathrm{mg} \cdot \mathrm{L}^{-1}\right)$ & & & & & \\
$\quad 0$ & $735^{\mathrm{x}}$ & $0.006 \mathrm{~b}$ & $44.89 \mathrm{a}$ & $17.88 \mathrm{a}$ & $84.8 \mathrm{a}$ \\
300 & 645 & $0.014 \mathrm{a}$ & $40.77 \mathrm{~b}$ & $14.47 \mathrm{~b}$ & $56.1 \mathrm{~b}$ \\
600 & 643 & $0.017 \mathrm{a}$ & $38.21 \mathrm{c}$ & $12.81 \mathrm{c}$ & $41.3 \mathrm{c}$ \\
Significance & & & & & \\
Harvest $(\mathrm{H})$ & 0.0136 & 0.9647 & 0.6227 & 0.1832 & 0.3189 \\
CPPU & $<0.0001$ & $<0.0001$ & $<0.0001$ & $<0.0001$ & $<0.0001$ \\
ABA & 0.5106 & $<0.0001$ & $<0.0001$ & 0.0028 & $<0.0001$ \\
CPPU $\times$ ABA & 0.4341 & 0.2105 & 0.5210 & 0.1039 & 0.2892 \\
H $\times$ CPPU & 0.7061 & 0.2782 & 0.1418 & 0.0162 & 0.0939 \\
H $\times$ ABA & 0.8038 & 0.5343 & 0.6508 & 0.9261 & 0.9113 \\
H $\times$ ABA $\times$ CPPU & 0.7167 & 0.8614 & 0.4841 & 0.1825 & 0.3127 \\
\hline
\end{tabular}

${ }^{2}$ Values are $\mathrm{H}$ means, $\mathrm{n}=48$

${ }^{\mathrm{y}}$ CPPU means, $\mathrm{n}=48$.

${ }^{\mathrm{x}} \mathrm{ABA}$ means, $\mathrm{n}=32$.

Means followed by a different letter within columns and factors are significantly different according to Duncan's multiple range test $(P \leq 0.05)$. 
(Düring et al., 1978; Han et al., 1996). Increases in these variables resulting from application of ABA were concentrationdependent in 2005, but in 2006, all ABA concentrations tested increased berry mass the same. Previously, we observed that ABA effects on berry mass were inconsistent (Peppi et al., 2006). There was no interaction between CPPU and ABA in relation to berry size or mass.

Grapes treated with CPPU were as firm, or firmer, than nontreated grapes, but berries treated with ABA were of similar or lesser firmness. Melillo (2005) observed that CPPU increased firmness of 'Redglobe' grapes, and Zabadal and Bukovac (2006) found a linear increase in firmness with CPPU concentration. The effect of ABA on grape berry firmness is less consistent, but most reports suggest that either ABA does not affect firmness or that it reduces it (Lee et al., 1997; Peppi et al., 2006).

Soluble solids were decreased by CPPU and titratable acidity was decreased by ABA, in agreement with others. Application of CPPU to seedless grapes generally delays their maturation (Dokoozlian et al., 1994, Melillo, 2005, Oswald, 1994, Reynolds et al., 1992), although Wolf et al., (1994) found that treatment with CPPU inhibited coloring but not soluble solids accumulation. In contrast, ABA did not affect soluble solids, in agreement with others (Han et al., 1996; Han and Lee, 2004; Kataoka et al., 1982; Lee et al., 1997; Peppi et al., 2006). There was no interaction between CPPU and ABA, so CPPU-treated fruit had lower soluble solids whether or not they were treated with ABA.

Treatment with CPPU or ABA had inverse effects on anthocyanin content as expected, and the treatment effects on pigments were reflected in different color characteristics. Thus, fruits treated with CPPU were lighter-colored, their color was more uniform, and they were less red and more green-colored. These results agree with those

Table 3. Effect of CPPU and ABA on berry weight, length and diameter of Flame Seedless grapes, 2006.

\begin{tabular}{|c|c|c|c|}
\hline Factor & $\begin{array}{c}\text { Berry } \\
\text { wt } \\
(\mathrm{g})\end{array}$ & $\begin{array}{l}\text { Berry } \\
\text { length } \\
(\mathrm{mm})\end{array}$ & $\begin{array}{l}\text { Berry } \\
\text { diam. } \\
(\mathrm{mm})\end{array}$ \\
\hline \multicolumn{4}{|l|}{$\overline{\mathrm{CPPU}}\left(\mathrm{g} \cdot \mathrm{ha}^{-1}\right)$} \\
\hline 0 & $4.98 \mathrm{~b}^{\mathrm{z}}$ & $20.7 \mathrm{ab}$ & $19.8 \mathrm{~b}$ \\
\hline 5 & $5.19 \mathrm{ab}$ & $20.6 \mathrm{~b}$ & $20.1 \mathrm{ab}$ \\
\hline 10 & $5.20 \mathrm{ab}$ & $20.5 \mathrm{~b}$ & $20.2 \mathrm{ab}$ \\
\hline 15 & $5.42 \mathrm{a}$ & $21.1 \mathrm{a}$ & $20.5 \mathrm{a}$ \\
\hline 20 & $5.06 \mathrm{~b}$ & $20.3 \mathrm{~b}$ & $19.9 \mathrm{~b}$ \\
\hline \multicolumn{4}{|l|}{$\mathrm{ABA}\left(\mathrm{mg} \cdot \mathrm{L}^{-1}\right)$} \\
\hline 0 & $4.78 \mathrm{~b}^{\mathrm{y}}$ & $20.1 \mathrm{~b}$ & $19.5 \mathrm{~b}$ \\
\hline 200 & $5.32 \mathrm{a}$ & $20.8 \mathrm{a}$ & $20.4 \mathrm{a}$ \\
\hline 400 & $5.34 \mathrm{a}$ & $20.9 \mathrm{a}$ & $20.3 \mathrm{a}$ \\
\hline 600 & $5.25 \mathrm{a}$ & $20.8 \mathrm{a}$ & $20.1 \mathrm{a}$ \\
\hline \multicolumn{4}{|l|}{ Significance } \\
\hline CPPU & 0.0453 & 0.0219 & 0.0206 \\
\hline $\mathrm{ABA}$ & 0.0002 & 0.0007 & 0.0002 \\
\hline $\mathrm{CPPU} \times \mathrm{ABA}$ & 0.8675 & 0.9005 & 0.9809 \\
\hline
\end{tabular}

${ }^{\mathrm{z}}$ Values are CPPU means, $\mathrm{n}=32$.

${ }^{y} \mathrm{ABA}$ means, $\mathrm{n}=40$.

Means followed by a different letter within columns and factors are significantly different according to Duncan's multiple range test $(P \leq 0.05)$. of Melillo (2005) who reported that 'Flame Seedless' is particularly sensitive to color inhibition associated with CPPU treatment. For example, anthocyanins of 'Flame Seedless', but not 'Crimson Seedless' or 'Redglobe', decreased in response to CPPU in experiments done by Melillo (2005). On the other hand, Oswald (1994) found that CPPU treatment lowered the color rating of all the seedless red cultivars he tested, including 'Crimson Seedless'. Reynolds et al. (1992) observed that CPPU-treated 'Sovereign Coronation' ['Lady Patricia' $\times$ 'Himrod' (Vitis vinifera $\times V$. labrusca) (Denby, 1977)] grapes were less purple-colored, and their juice had less anthocyanins, than the untreated control fruits. Han and Lee (2004) also observed lower anthocyanin levels in CPPU-treated 'Kyoho' (Vitis vinifera L. $\times V$. labrusca L.) grape compared with untreated fruit or with fruit treated with $\mathrm{GA}_{3}$. This effect was negated by application of $\mathrm{ABA}$; in fact, ABA treatment doubled the anthocyanin content compared with untreated control fruit.

Applications of ABA are generally effective at increasing the anthocyanin content of grapes (Han et al., 1996; Kataoka et al., 1982; Lee et al., 1997), including 'Flame Seedless' (Peppi et al., 2006). We show that ABA treatment can even help overcome the severe color inhibition caused by CPPU. Fruit treated with 5 to $20 \mathrm{~g} \cdot \mathrm{ha}^{-1} \mathrm{CPPU}$ plus 400 $\mathrm{mg} \cdot \mathrm{L}^{-1} \mathrm{ABA}$ had similar or even better color than CPPU-untreated fruit in 2006 (Figs. 1, 2, and 3). In 2006, fruit with $5 \mathrm{~g} \cdot \mathrm{ha}^{-1} \mathrm{CPPU}$ needed only $200 \mathrm{mg} \cdot \mathrm{L}^{-1} \mathrm{ABA}$ to achieve a color considered acceptable by the market, and fruit treated with $600 \mathrm{mg} \cdot \mathrm{L}^{-1} \mathrm{ABA}$ were darker and more red-colored than nontreated

Table 4. Effect of CPPU and ABA on the soluble solids, titratable acidity, puncture resistance, and anthocyanin content of Flame Seedless grapes, 2006.

\begin{tabular}{|c|c|c|c|c|}
\hline Factor & $\begin{array}{l}\text { Soluble solids } \\
\left({ }^{\circ} \text { Brix }\right)\end{array}$ & $\begin{array}{l}\text { Titratable acidity } \\
\qquad\left(\mathrm{g} \cdot \mathrm{L}^{-1}\right)\end{array}$ & $\begin{array}{l}\text { Firmness } \\
\text { (g) }\end{array}$ & $\begin{array}{c}\text { Anthocyanins } \\
\left(\mathrm{mg} \cdot \mathrm{cm}^{-2}\right)\end{array}$ \\
\hline \multicolumn{5}{|l|}{$\overline{\operatorname{CPPU}}\left(\mathrm{g} \cdot \mathrm{ha}^{-1}\right)$} \\
\hline 0 & $15.9 \mathrm{a}^{\mathrm{z}}$ & 4.58 & $385.77^{z}$ & $0.015 \mathrm{a}$ \\
\hline 5 & $15.5 \mathrm{ab}$ & 4.65 & 394.26 & $0.011 \mathrm{~b}$ \\
\hline 10 & $14.8 \mathrm{c}$ & 4.68 & 389.31 & $0.009 \mathrm{~b}$ \\
\hline 15 & $15.0 \mathrm{bc}$ & 4.62 & 410.69 & $0.010 \mathrm{~b}$ \\
\hline 20 & $14.8 \mathrm{c}$ & 4.79 & 395.73 & $0.012 \mathrm{~b}$ \\
\hline \multicolumn{5}{|l|}{$\mathrm{ABA}\left(\mathrm{mg} \cdot \mathrm{L}^{-1}\right)$} \\
\hline 0 & $15.5^{\mathrm{y}}$ & $4.91 \mathrm{a}$ & $440.62 \mathrm{a}^{\mathrm{y}}$ & $0.007 \mathrm{c}$ \\
\hline 200 & 15.2 & $4.60 \mathrm{~b}$ & $400.82 \mathrm{~b}$ & $0.010 \mathrm{~b}$ \\
\hline 400 & 14.9 & $4.48 \mathrm{~b}$ & $370.63 \mathrm{c}$ & $0.014 \mathrm{a}$ \\
\hline 600 & 15.2 & $4.65 \mathrm{~b}$ & $369.56 \mathrm{c}$ & $0.015 \mathrm{a}$ \\
\hline \multicolumn{5}{|l|}{ Significance } \\
\hline CPPU & 0.0030 & 0.2792 & 0.2287 & 0.0031 \\
\hline $\mathrm{ABA}$ & 0.1977 & 0.0001 & $<0.0001$ & $<0.0001$ \\
\hline $\mathrm{CPPU} \times \mathrm{ABA}$ & 0.4122 & 0.9462 & 0.3562 & 0.2468 \\
\hline
\end{tabular}

${ }^{\mathrm{z}}$ Values are CPPU means, $\mathrm{n}=32$.

${ }^{\mathrm{y}} \mathrm{ABA}$ means, $\mathrm{n}=40$.

Means, within columns and factors, followed by a different letter are significantly different according to Duncan's multiple range test $(P \leq 0.05)$.

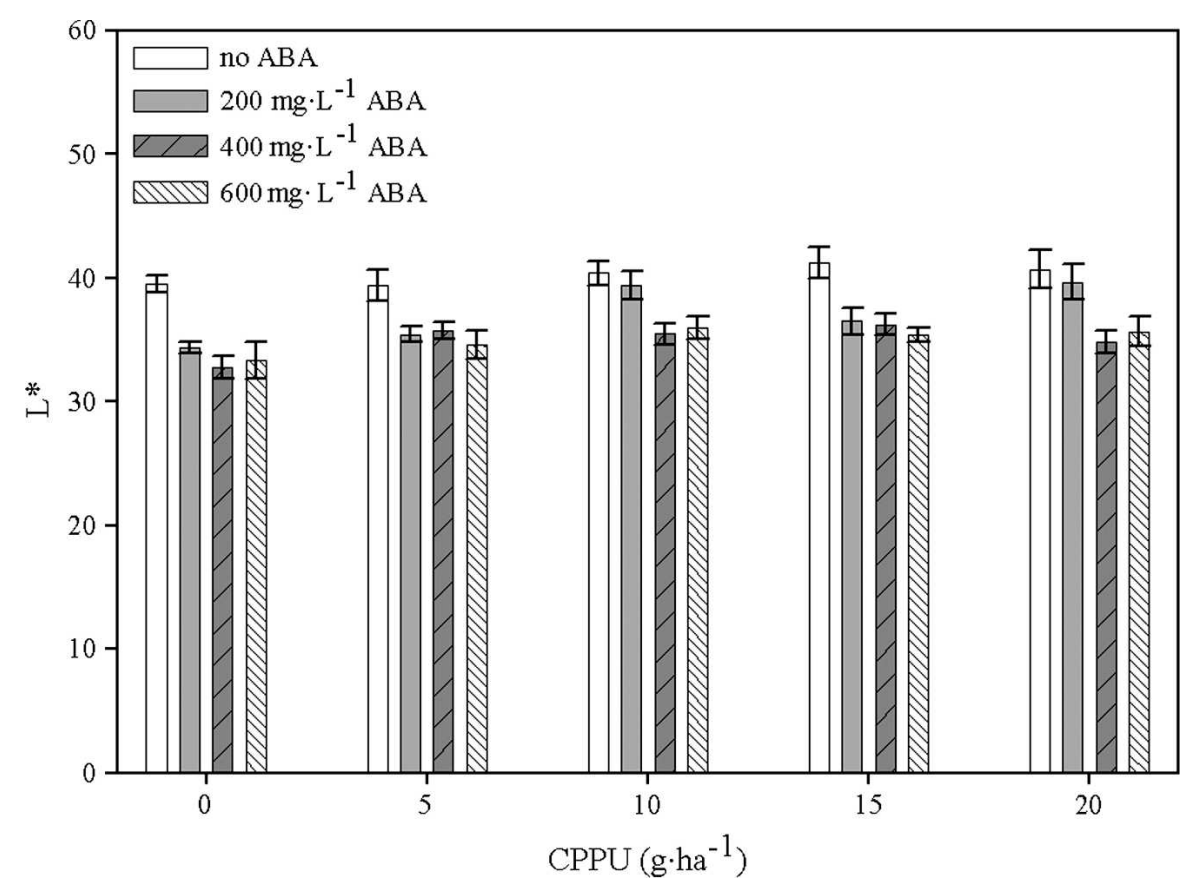

Fig. 1. Effect of forchlorfenuron on the lightness (L*) of abscisic acid-treated 'Flame Seedless' grapes, 2006. 


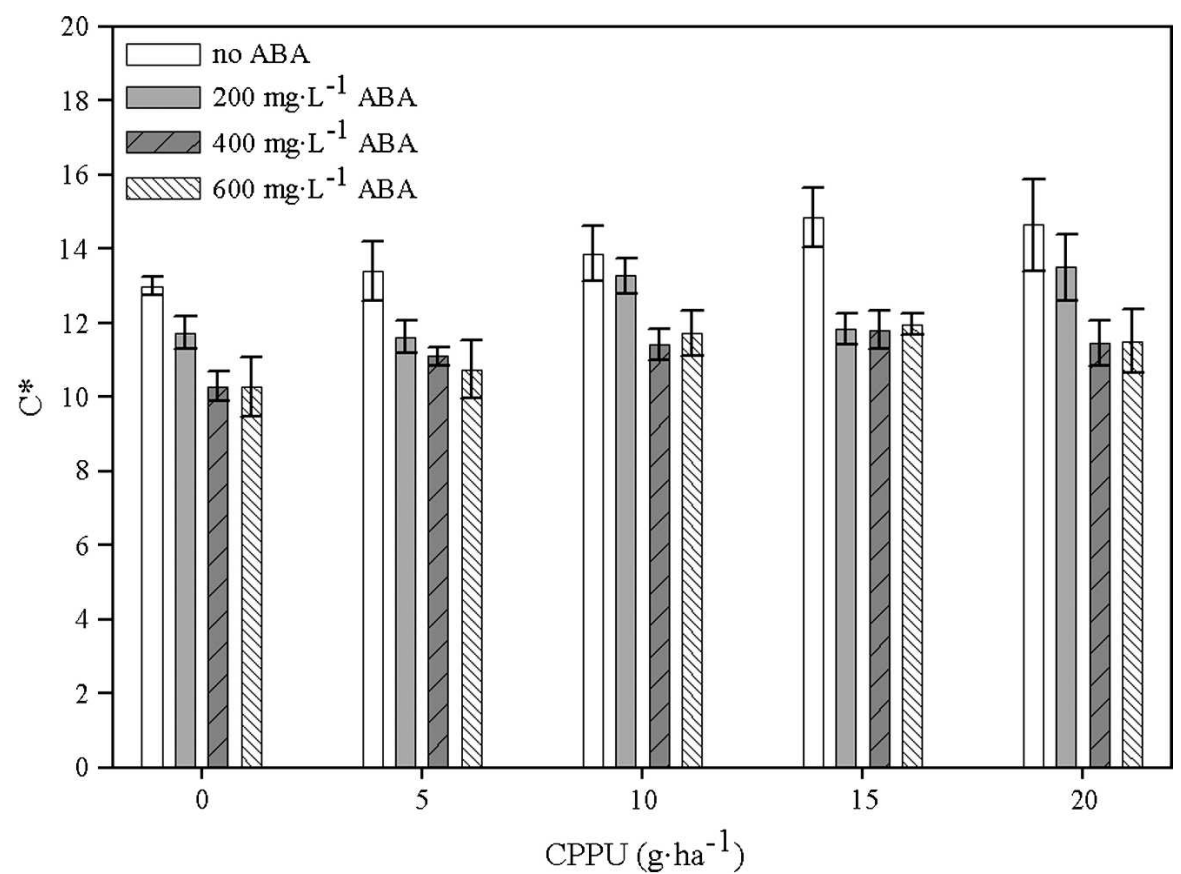

Fig. 2. Effect of forchlorfenuron on the chroma ( $\left.\mathrm{C}^{*}\right)$ of abscisic acid-treated 'Flame Seedless' grapes, 2006.

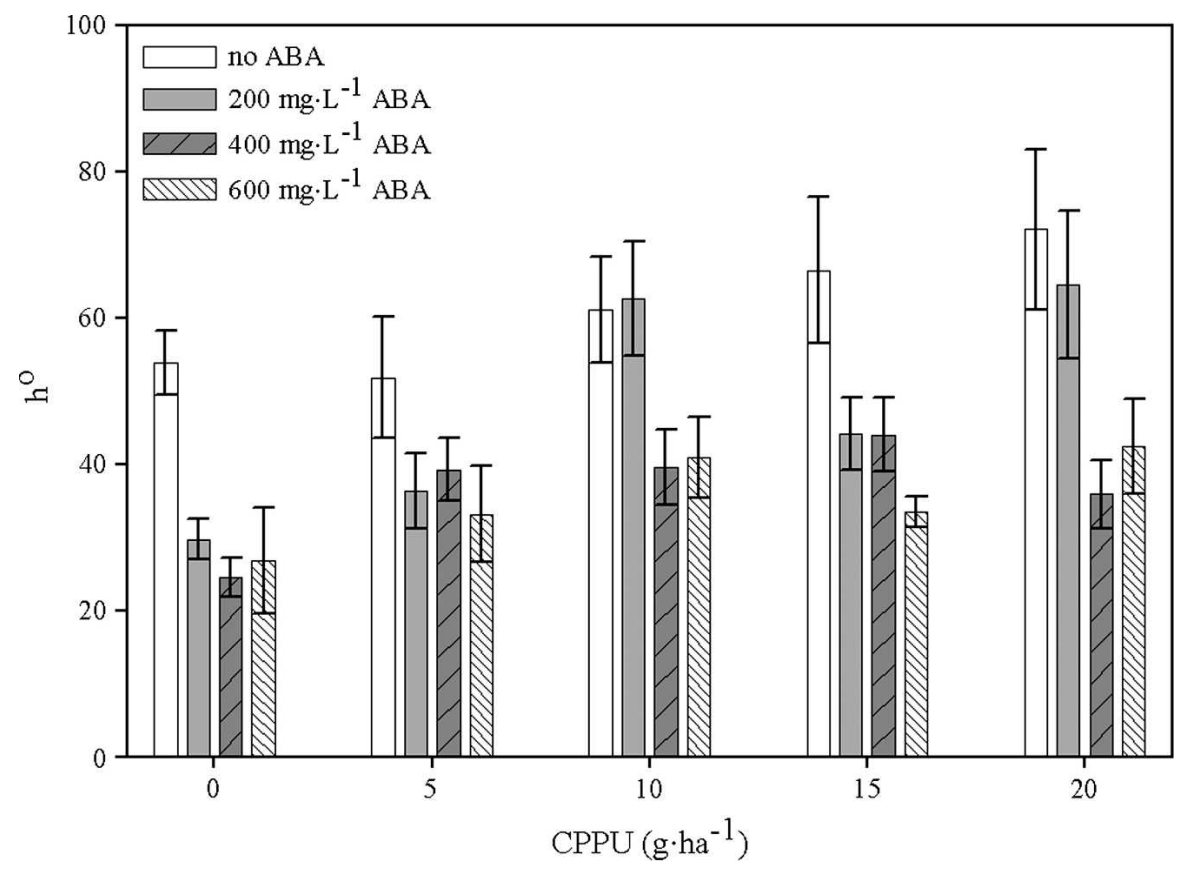

Fig. 3. Effect of forchlorfenuron on the hue angle $\left(\mathrm{h}^{\circ}\right)$ of abscisic acid-treated 'Flame Seedless' grapes, 2006.

fruits regardless of the CPPU treatment (Figs. 1 and 3 ). In conclusion, the combined use of CPPU and ABA has the potential to improve the quality of 'Flame Seedless' table grapes because the negative effects of CPPU on maturity, and particularly on color, can to some extent be overcome by ABA.

\section{Literature Cited}

Denby, L.G. 1977. 'Sovereign Coronation' grape. HortScience 12:512.
Diaz, D.H. and L.A. Maldonado. 1992. Forchlorfenuron effects on berry size and maturity of Perlette and Flame Seedless grapes. In: Proc. Ann. Meet. Plant Growth Reg. Soc. Amer. 19:123-128.

Dokoozlian, N.K. and D.J. Hirschfelt. 1995. The influence of cluster thinning at various stages of fruit development on Flame Seedless table grapes. Amer. J. Enol. Viticult. 46:429-436.

Dokoozlian, N.K., M.M. Moriyama, and N. Ebisuda. 1994. Forchlorfenuron (CPPU) increases the berry size and delays the maturity of Thompson
Seedless table grapes, p. 63-68. In: International Symposium on Table Grape Production Proceedings Anaheim. Amer. Soc. Enol. Viticult.

Düring, H., G. Alleweldt, and R. Koch. 1978. Studies on hormonal control of ripening of grape vines. Acta Hort. 80:397-405.

Han, D.H. and C.H. Lee. 2004. The effects of $\mathrm{GA}_{3}$, CPPU and ABA applications on the quality of Kyoho (Vitis vinifera L. $\times$ V. labrusca L.) grape. Acta Hort. 653:193-197.

Han, D.H., S.M. Lee, C.H. Lee, and S.B. Kim. 1996. Effects of ABA and ethephon treatments on coloration and fruit quality in Kyoho grape. J. Kor. Soc. Hort. Sci. 37:416-420.

Jensen, F.L., J. Kissler, W. Peacock, and G. Leavitt. 1975. Effect of ethephon on color and fruit characteristics of Tokay and Emperor table grapes. Amer. J. Enol. Viticult. 26:79-81.

Kataoka, I., A. Sugiura, N. Utsunomiya, and T. Tomana. 1982. Effect of abscisic acid and defoliation on anthocyanin accumulation in Kyoho grapes (Vitis vinifera L. $\times$ V. labruscana Bailey). Vitis 21:325-332.

Lee, K.S., J.C. Lee, Y.S. Hwang, and I.B. Hur. 1997. Effects of natural type (S)-(+)-abscisic acid on anthocyanin accumulation and maturity in 'Kyoho' grapes. J. Kor. Soc. Hort. Sci. 38:717-721.

McGuire, R.G. 1992. Reporting of objective color measurements. HortScience 27:1254-1255.

Melillo, M. 2005. Influence of synthetic cytokinins on the growth and composition of several table grape (Vitis vinifera L.) cultivars. University of California, Davis, MS Thesis.

Nickell, L.G. 1986. The effects of N-(2-chloro-4pyridil)- $\mathrm{N}^{\prime}$-phenylurea and the 3-chloro-benzil ester of dicamba on the growth and sugar content of grapes. Acta Hort. 179:805806.

Oswald, T.L. 1994. Influence of CPPU (N-(2chloro-4-pyridil)-N-phenylurea) on the berry size and fruit composition of several Vitis vinifera table grape cultivars. California State University, Fresno, MS Thesis.

Peppi, M.C. 2004. Color Development studies in table grapes. Univ. Calif., Davis, MS Thesis.

Peppi, M.C., M.W. Fidelibus, and N. Dokoozlian. 2006. Abscisic acid application timing and concentration affect firmness, pigmentation and color of 'Flame Seedless' grapes. HortScience 41:1440-1445.

Reynolds, A.G., D.A. Wardle, C. Zurowski, and N.E. Looney. 1992. Phenylureas CPPU and thiadiazuron affect yield components, fruit composition, and storage potential of four seedless grape selections. J. Amer. Soc. Hort. Sci. 117:85-89.

Taiz, L. and E. Zeiger. 2002. Plant physiology. 3rd ed. Sinauer Associates, Inc., Pub., Sunderland, MA.

Winkler, A.J., J.A. Cook, W.M. Kliewer, and L.A. Lider. 1974. General viticulture. 2nd ed. Univ. of Calif. Press, Berkeley, CA.

Wolf, E.E., J.A. Viljoen, A. Nieuwenhuys, and J.T Loubser. 1994. The effect of forchlorfenuron on bunch quality in table grapes, p. 50-53. In: International Symposium on Table Grape Production Proceedings Anaheim. Amer. Soc. Enol. Viticult.

Zabadal, T.J. and M.J. Bukovac. 2006. Effect of CPPU on fruit development of selected seedless and seeded grape cultivars. HortScience 41:154-157. 